\title{
Performativity, Big Data and Higher Education: The Death of the Professor?
}

\author{
Peter Roberts \\ Professor of Education, University of Canterbury, New Zealand \\ peter.roberts@canterbury.ac.nz
}

\begin{abstract}
In his classic work, The Postmodern Condition: A Report on Knowledge, Jean-Françios Lyotard prophesised the death of the age of the Professor. Writing at the end of the 1970s, Lyotard could see that in contexts where knowledge was regarded as a commodity, and where the question of truth was becoming subservient to the question of what sells, the importance of university teachers would increasingly be questioned. In the decades that followed the publication of The Postmodern Condition, many of the trends observed by Lyotard have become cemented in policy and practice. This paper argues that while the age of the Professor is not yet dead, it is dying - slowly but steadily, in a manner that is more evident in some fields than others. Given the dominance of economic goals in shaping educational agendas, the triumph of the performativity principle, and the obsession with measuring and marketing almost everything, support for scholars in the humanities in particular has been progressively eroded. This process of dying is, however, by no means complete, and a rebirth of the age of the Professor, perhaps in a slightly different form, remains a possibility that should not be ruled out.
\end{abstract}

\section{Keywords}

knowledge - performativity - big data - higher education - Lyotard - death

Jean-Françios Lyotard's La Condition Postmoderne: Rapport sur le Savoir first appeared in 1979, a date that now, in our fast-paced world, seems almost a lifetime ago. Published in English translation in 1984, The Postmodern Condition: 
A Report on Knowledge (Lyotard, 1984) has become a classic reference point for those seeking to understand pivotal changes in late 2oth century culture and thought. Writing well before the rise of the Internet as a medium of mass communication, Lyotard could see that new language-based technologies would have far-reaching consequences for higher education. In contexts where knowledge was regarded as a commodity, and where the question of truth was becoming subservient to the question of what sells, the importance of university teachers would increasingly be questioned. We would, Lyotard predicted, see the death of the age of the Professor. In the decades that followed the publication of The Postmodern Condition, many of the trends observed by Lyotard have become cemented in policy and practice. This paper argues that while the age of the Professor is not yet dead, it is dying. This has been a slow, steady, often unnoticed process, more evident in some fields than others. Given the dominance of economic goals in shaping educational agendas, the triumph of the performativity principle, and the obsession with measuring and marketing almost everything, support for scholars in the humanities has been progressively eroded. In the era of "big data", study in the liberal arts, under the guidance of a teacher who seeks knowledge for its own sake rather than its exchange value, can seem like a quaint ideal - a relic of an almost forgotten past. This process of dying is, however, by no means complete, and a rebirth of the age of the Professor, perhaps in a slightly different form, remains a possibility that should not be ruled out.

2

Knowledge, Performativity and the Death of the Professor

Two features of The Postmodern Condition have been particularly influential in shaping subsequent scholarship: first, Lyotard's definition of the postmodern as "incredulity toward metanarratives" (Lyotard, 1984, p. xxiv), and second, his discussion of changes in higher education in computerised societies. These two areas of influence - one more self-evidently philosophical, the other more directly relevant to policy - are, of course, closely related. The point of connection between them is Lyotard's account of changes in the nature, status and function of knowledge. The Postmodern Condition is not a philosophical treatise on knowledge but neither is it merely a "report" as suggested by the sub-title of the book. Instead, Lyotard provides a contextualised epistemology, relevant to the problems of his time but with much that still rings true today.

The hypothesis underpinning The Postmodern Condition is that "the status of knowledge is altered as societies enter what is known as the post-industrial age and cultures enter what is known as the postmodern age" (p. 3). Lyotard 
distinguishes between two forms of knowledge, narrative and scientific, arguing that in computerised societies, it is the latter that has come to dominate over the former. This process has been underway from the late 19th century and has accelerated with the emergence of new language-based technologies in the second half of the 2oth century. Modern sciences and fields of knowledge have relied on appeals to grand narratives "such as the dialectics of Spirit, the hermeneutics of meaning, the emancipation of the rational or working subject, or the creation of wealth" (p. xxiii). But with metaphysics and the university in crisis, grand narratives have lost the authority they once had and have been replaced by "narrative language elements" (p. xxiv). We live in and through these heterogeneous language elements, playing different language games. Instead of universals - ethical principles that apply to all, heroes for all cultures and contexts, goals that inspire everyone - there is a focus on the little and the local, the particular and the specific. Postmodern knowledge "refines our sensitivity to differences and reinforces our ability to tolerate the incommensurable" (p. xxv).

Lyotard identifies a central problem for knowledge: that of legitimation. Legitimation has to do with how authority is exercised to make something e.g., a law, or a scientific utterance - acceptable. In the process of legitimation, knowledge and power are intertwined: "who decides what knowledge is, and who knows what needs to be decided?" (p. 9). In science, Lyotard points out, there has traditionally been a strong connection between research and teaching (pp. 24-25). Scientists pass on their knowledge to others who are expected, in time, to acquire similar expertise to their teachers. Where in the beginning it is assumed that one knows and the other does not, over time the student's view of the teacher changes. Students become aware that their teachers too are still learning; in this manner, they are inducted into the dialectics of scientific research (p. 25). Scientific knowledge, like narrative knowledge, relies on "moves" in a game structured by a set of generally accepted rules. What counts as a good move in the realm of narrative knowledge cannot be judged by the rules that apply in science, and vice versa. For Lyotard, the diversity of different discourses is something to be valued, with a sense of wonder, just as we might marvel at diversity in the plant or animal kingdom (p. 26). In practice, however, such an attitude tends not to prevail. Those who work in the narrative realm, accepting the limits of their knowledge, may display a certain tolerance towards science, but the reverse does not apply. For the scientist, narrative knowledge is "savage, primitive, underdeveloped, backward, alienated, composed of opinions, customs, authority, prejudice, ignorance, ideology" (p. 27). The inequality between the two forms of knowledge is consistent with the broader history of cultural imperialism in the West. What makes this 
particular kind of imperialism distinctive is that it is driven by the legitimation imperative. Science, despite its rejection of narrative knowledge, remains dependent on it. The very act of asserting its superiority, its truth, relies upon a narrative of legitimation.

The abandonment of metanarratives in postmodernity poses problems not just for those who work with narrative knowledge but for scientists as well. Boundaries between disciplines are breaking down, new fields are emerging, and in place of the old hierarchy of subjects a new "flat" structure of different domains of inquiry appears. The crisis faced by scientific knowledge is reflective of a broader challenge to the legitimating power of knowledge. In postmodernity, speculative philosophy and humanistic narratives prove less persuasive than they have been in the past, but so too does science. Knowledge in the post-industrial age has become an "informational commodity" (p. 5): a key force of production and pivotal element in the quest for power. Conceived in this way, knowledge is desirable not so much for its truth value as its exchange value; it is something to be sold, traded and purchased, in the same manner as other commodities in a competitive marketplace. The twin processes of commodification and computerisation contribute to an exteriorisation of knowledge from knowers (p. 4). What matters is not knowledge itself, or the presence of a knowing subject, but what knowledge can do. When knowledge is conceived in this way, the performativity principle - enhancing efficiency by maximising outputs relative to inputs (cf. Locke, 2015, p. 248) - becomes paramount. A move in the language game of technology is considered desirable not because it is just or beautiful but because it minimises energy expenditure (Lyotard, 1984, p. 44). Technology can play an important role in generating revenue, while fields of inquiry based on narrative knowledge become increasingly marginalised. In a world where "whoever is wealthiest has the best chance of being right" (p. 45), the arts and humanities are regarded as worthless. In the global battle for economic domination, access to, and control over, information becomes vital. Under such conditions, nation states can come to be seen as a hindrance to the circulation and exchange of knowledge in its commodified form, and multinational corporations become ever more powerful. Existing differences between "developed" and "developing" nations will be exacerbated, and with advances in technology, many of the functions currently performed by human beings will be taken over by machines. The goal of higher education becomes one of optimising its contribution to "the performativity of the social system" (p. 48).

If it is accepted that there is an "established body of knowledge", questions arise as to what from that body of knowledge is to be transmitted, to whom, in what ways, and with what consequences or effects (p. 48). The answers to these 
questions are important in shaping how a university works. In each case, under contemporary conditions, the performativity criterion is applied. Particular attention is paid to the development of two kinds of skills: first, those aimed at global competitiveness, and second, those focused on maintaining internal social cohesion (p. 48). In the past, the latter would have been built upon an emancipation narrative, but that will no longer suffice; universities are now tasked with supplying people who will be able to fulfil pragmatic roles in the social system. The ends of higher education become functional rather than idealistic. The model of the "democratic" university, premised on humanist assumptions about the emancipatory power of education, offers "little in the way of performance" (p. 49). While universities will continue to prepare people for the professions, they will also increasingly take on the task of retraining those already in the workforce. If enhancing the system's performance is the overriding goal, any "experimentation in discourse, institutions, and values" will be seen as having "little or no operational value" and will be left to networks outside the university (p. 50).

While the specific ways in which universities respond to these challenges will vary, the overall effect of the performativity principle is to "subordinate the institutions of higher learning to the existing powers" (p. 5o). If knowledge is no longer sought for its own sake, "its transmission is no longer the exclusive responsibility of scholars and students" (p. 50). The idea of university autonomy has, Lyotard suggests, already been compromised by the fact that teachers in institutions of higher education do not determine their own budgets; they can only allocate funds assigned to them by others. From a functionalist perspective, universities transmit "an organized stock of established knowledge" (p. 5o), a task that need not be reliant on a Professor standing in front of students. If learning can be translated in a computer language, the didactic function of the university could be given over to machines. The machines would, Lyotard imagines, link "traditional memory banks" such as libraries and "computer data banks" to "intelligent terminals placed at the students" disposal" (p. 50). There would still be a place for teaching of certain kinds in such a system: people would, for example, be needed to show others how to use the intelligent terminals. Training in informatics and telematics could, from this perspective, be seen as a useful addition to the university curriculum. Technical skills of this kind have a more obvious connection with improvements in efficiency and performance than knowledge of what is "true" or "untrue", or "just" or "unjust", and will thus be highly valued (p. 51).

It is, Lyotard maintains, "only in the context of the grand narratives of legitimation - the life of the spirit and/or the emancipation of humanity - that the partial replacement of teachers by machines may seem inadequate or 
even intolerable" (p. 51). In contexts where the key drivers are power, performance and control, such narratives prove inadequate and irrelevant in motivating learners to acquire knowledge (p. 51). Lyotard envisages a "vast market for competence in operational skills" opening up, with those who possess this form of knowledge being in high demand (p. 51). Making efficient and strategic use of data to solve immediate problems will be seen as particularly valuable. Knowledge in the postmodern condition can be conceived as a game of "perfect information", with data, in theory at least, being no longer the exclusive preserve of scientific specialists but available to an expert in any field (p. $\left.5^{2}\right)$. In such games, the advantage rests with those who can arrange and connect data in new ways. If all players are equally competent, it is "imagination" - the ability to "make a new move" or to "change the rules of the game" - that matters (p. 52). "Brainstorming" and teamwork can be harnessed to improve performance, while the development of imaginative minds may remain the preserve of a privileged few. In both cases, however, "the process of delegitimation and the predominance of the performance criterion are sounding the knell of the age of the Professor: a Professor is no more competent than memory bank networks in transmitting established knowledge, no more competent than interdisciplinary teams in imagining new moves or new games" (p. 53). Professors, Lyotard implies, will not merely be seen as unnecessary; they may, in the quest for efficiency, be regarded as a hindrance to progress. Their knowledge and experience will be devalued or disregarded, and they will "die" along with the humanistic narratives that once sustained them.

Over the years, The Postmodern Condition has attracted a good deal of attention from educationists (see, for example, Gietzen, 2010; Irwin, 2018; Koller, 2003; Lange, 2015; Locke, 2015; Marshall, 1999; Nuyen, 1992; Peters, 1989, 1995, 1997, 2006; Roberts, 1998; Usher, 2006; Zembylas, 200o), and key questions addressed in the book remain as relevant in our present age as they were in Lyotard's time. Two decades ago, in reflecting on Lyotard's work, it was possible to claim: "In one sense, the full impact of computerisation has yet to be felt in the tertiary sector: academics have not yet been replaced (at least not in large numbers) by machines. Given what we know to be possible (in terms of processing power and technical sophistication) there is at present only rather limited use of the sort of data exchange systems envisaged by Lyotard" (Roberts, 1998, p. 5). Is this still true today? Yes and no. We continue to have universities, as physical spaces with campus grounds and buildings. On those campuses there are academic 
staff (faculty), who teach students on a face-to-face basis in classrooms, laboratories and lecture theatres. Professors are very much alive and well, with a presence not only in students' lives but in the wider world, with their expertise still in demand, in some fields at least, in the media, by governments, and in the corporate world. Professors and other faculty members are more active than ever in research, prompted in part by some of the trends foreshadowed by Lyotard's analysis - in particular, the emergence of new performance-based research funding regimes. Yet, death and dying, in a symbolic sense, are everywhere in the contemporary university. These changes are, in part, a reflection of developments in online education, yet they also signal deeper shifts in the way power is exercised across the globe. The process of commodifying knowledge, and of reconfiguring higher education in accordance with the performativity principle, is an incomplete project, as the discussion below attempts to demonstrate.

The development of Moocs - Massive Open Online Courses - provides an interesting contemporary example of what might be termed a partial victory for performativity. MOOcs are a kind of hybrid, both relying on Professors and dispensing with them. Professors may provide the initial content, through lectures or other forms of teaching that do not look too dissimilar to the pedagogical approaches adopted in an earlier era. But once this material has been recorded, it is then distributed widely - "beyond" the Professor - via online platforms. As Longstaff (2017, p. 314) observes, "[t]hrough a modular, online, video-based format, Moocs offer a way for universities to market their wares to a global audience on an unprecedented scale, at little to no cost to participants". Some commentators distinguish between well-financed, teacherfocused "xMOOCs", with an emphasis on "knowledge duplication", and learner-focused "cMOOCs", where knowledge is created in a more organic way via connections between students (cf. Baggaley, 2013, p. 371; Billsberry, 2013, p. 741; Guardia, Maina \& Sangra, 2013, p. 2). Moocs of both kinds have spread rapidly, generating considerable popular interest in their impact on conceptions and practices of education. This was evident some years ago, for instance, when The New YorkTimes declared 2012 to be the year of the MOос (Evans \& McIntrye, 2016, p. 313). Moocs deal with student numbers that are truly mind-boggling. In 2011, two academics at Stanford University provided open access to their course on Artificial Intelligence, and attracted 58,00o students (Howarth et al., 2016, p. 75). The same university reported enrolments of over 300,00o students across three computer courses (Billsberry, 2013, p. 740). There are now hundreds of institutions in partnership with Coursera, edX and Udacity, delivering Moocs to more than 10 million participants worldwide (Longstaff, 2017, p. 315). 
Enrolment numbers in many MOocs may be staggeringly high by "age of the Professor" standards, but completion rates are low, averaging only about $13 \%$ (Howarth et al., 2016, p. 75). Moreover, despite hopes that moocs might play an important part in the process of lifting people out of poverty - an affordable way of allowing people to secure the knowledge they need to gain employment or improve in their existing jobs (Evans \& McIntrye, 2016, p. 314) - in practice it has been the "wealthiest, most educated citizens of developing nations" who have been most likely to take these courses (Evans \& McIntrye, 2016, p. 315). Moocs are still evolving, but at present they remain in an ambiguous position when considered against the backdrop of Lyotard's knell of the age of the Professor thesis. Some have been set up with contributions from Professors at prestigious universities such as Harvard, MIT and Stanford, but others have emerged as for-profit start-ups (cf. Jona \& Naidu, 2014, p. 141). Some might be seen as a genuine attempt to democratise knowledge; others merely serve as "shop windows" for universities - designed to enhance their "brand" in a competitive marketplace. Moocs could become a key means for enacting the performativity principle and enhancing the relentless drive for efficiency, but if the academic standards they uphold are to be high, they are expensive (and in that sense, "inefficient") to develop. In addition to Professors or other academic staff, they can require "a film or TV director, an editor, animators, designers, lighting engineers, web design engineers, actors, and educational designers" (Billsberry, 2013, p. 744).

We need, however, to dig a little deeper than this and ask ourselves exactly what has "died", or is in the process of dying, in higher education. A clue to answering this question lies in the precise wording of Lyotard's statement on the fate of the Professor. He refers to the knell of the age of the Professor. "Knell" in its noun form means the sound made by the slow, solemn ringing of a bell, typically to mark a death - hence the frequent conjoining of the two terms as "death knell". Lyotard is thus providing a signal of a death - one that he believes will be greeted with a certain solemnity or sadness. But it is not the Professor him- or herself who has died here; it is the age to which the Professor belongs. Lyotard's point, then, is not so much that there will be an immediate or literal withering away and eventual complete disappearance of the Professoriate; rather, he is sounding a note to signal the dying of a period in history. The "age" of the Professor includes the practices, the attitudes, and the forms of life characteristic of that historical moment. This is an age that stretches back at least 1000 years, to the birth of the medieval university, but its roots go much deeper than this - in the West, to the ancient Greeks and the founding of Plato's academy, and in the East perhaps even further than this. The idea of having specialised forms of esteemed knowledge, held by relatively few people 
and passed on via rigorous training, mentoring and study, stretches back millennia, and given this deep history, is unlikely to simply evaporate. Traces of the idea will remain, no matter how radical and far-reaching policy and political changes may be. So, it is more correct, perhaps, to speak of the "death" of the Professor not as a single, terminal event, but rather as an ongoing, multifaceted process of dying.

The distinctively modern expression of the ancient forms of cultural and intellectual life that have created the "age of the Professor" has, as Lyotard points out, a strong humanist and emancipatory thrust (cf. Peters \& Roberts, 1999). It is tied to Enlightenment notions of knowledge setting us free. Knowledge liberates us, both in a manner that is visible externally, by opening up opportunities that would otherwise be closed, and in an inner sense, by freeing the mind to realise its fuller potential. Knowledge, on the Enlightenment view, is inextricably linked with the activities of individual conscious human agents. "Knowing" is a human activity, and the transmission of knowledge is something that occurs from one person to another (or many others). Lyotard's prediction that knowledge would increasingly be produced in order to be sold has, over the decades, proven to be uncannily accurate. "Knowledge" in the traditional, humanistic sense has been both problematized and marginalised. Its commodified form, as information with an exchange value traded between "sellers" and "buyers", has become ever more prominent, both within and beyond universities. Yet, the transition that Lyotard describes is by no means complete. Knowledge of the more traditional humanistic kind is, in many contexts, under threat, even under "siege" (cf. Nussbaum, 2010), and is in that sense "dying", but it has not completely disappeared. Lyotard recognised that scientific knowledge relies on narrative knowledge for its own justification, but there is more to it than that. In contemporary higher education, the narratives harnessed to justify institutional changes - ironically, sometimes including those most at odds with the traditional ideal of the university - bear the definite imprint of the humanistic knowledge most at risk in the age of performativity.

Most universities publish "vision statements" and "strategic plans", and the language employed in such documents frequently draws on emancipatoryideals espoused in earlier times. It is not uncommon, for example, for these statements to refer, in one way or another, to students and/or faculty members "making a difference" in the world, and this is assumed to be a worthwhile difference. In the policy documents developed by government bodies too, there remain traces of the very form of knowledge most evidently lacking in the content and overall direction of the policy. New Zealand's Tertiary Education Strategy (New Zealand Government, 2014), for instance, like many documents of this type, places a heavy emphasis on the need for tertiary education to contribute 
to international economic competitiveness. Developed under the previous National government, the Strategy stresses the principle of "performance" as the driver for institutional and individual academic activity, and it pushes tertiary education organisations to respond to the demands of employers and markets. The social benefits of tertiary education barely warrant a mention, and it is as if those who write such statements barely know what to say when speaking about such benefits. The humanities are conspicuous by their absence in the Strategy, and it is clear that they are accorded little importance. As if to leave no doubt about where it was believed our efforts should be focused, a "Productivity Commission" was established, and it was left to that body to produce the only substantial government-funded document on tertiary education during National's nine years in power (New Zealand Productivity Commission, 2017). The message to those who work in the sector is clear: perform, produce and prosper. This reinforces the dominance of economics in shaping higher education policy, a trend that has been underway for more than two decades (Fitzsimons, Peters \& Roberts, 1999). And yet, for all that, humanistic knowledge has not been entirely extinguished. It remains in the voices that sit on the edges of policy - that frame it and preface it and promote it. The statements made in the Forewords produced by Ministers (or their officials) in strategy documents often contain fragments of the older discourse that is most under threat in the era of performativity. They will sometimes speak of values and principles that seem radically at odds with the stark messages conveyed in the substance of a policy document. Press statements also frequently hark back to an earlier era in the language they use to "sell" a new policy direction. Even references to the most tired and vacuous of policy terms - "relevance", "quality" and the like (Ministry of Education, 2006, 2009) - have an epistemological heritage that is seldom acknowledged but still sitting quietly in the background. Humanistic knowledge, in short, may be under attack or devalued or ignored, but it finds its way into even the most unlikely of policy places. It is, we might say, being put to death but is refusing to die easily.

In New Zealand, universities have a statutory obligation, under an amendment to the Education Act of 1989, to accept a role as "critic and conscience of society". This role receives little or no direct discussion in most government policy documents on tertiary education, yet it provides some protection for academics who wish to voice concerns about the economic and social direction the country is taking (Roberts, 2007). But even without a legislative warrant of this kind, academics are unlikely to be entirely silent. The overall thrust of the reform process, across the Western world, has been broadly in accordance with Lyotard's predictions, but dissent has not disappeared. Indeed, some of the developments foreshadowed by Lyotard have themselves provided the means 
for mustering collegial support in resisting the reforms. The computerised terminals in Lyotard's analysis might be seen as a sketch of what was to come with the Internet, and whatever else the Internet does, it at least has the potential to allow Professors, students and social activists to connect, engage and organise with others, all over the world, with a speed and efficiency that could barely have been imagined just a few decades ago. Lyotard saw that computerisation could assist groups in "discussing metaprescriptives" by providing the information that would usually be lacking in making "knowledgeable decisions" (Lyotard, 1984, p. 67). He favoured an opening up of the "data banks", allowing free access to knowledge - with its inexhaustible reserve of possible utterances - for all members of the public. Language games would, he maintained, then become "games of perfect information at any given moment" (p. 67). Yet he also envisaged the prospect of computerisation becoming something much more sinister in a market system: an instrument of terror that would control and regulate knowledge in accordance with the performativity principle. To date, neither of these scenarios has fully come into being. Elements of both are evident, but the stark "either/or" set of possibilities signalled by Lyotard has not yet eventuated.

Lyotard's statements on dual possibilities in the computerisation of society appear at the very end of The Postmodern Condition. This is arguably both the most important and the weakest part of the book. His brief comments on opening up the data banks are offered as a sketch of a politics that "would respect both the desire for justice and the desire for the unknown" (p. 67), yet the reader is ill-prepared for a normative claim of this kind. Indeed, the appeal to justice seems at odds with the critique of modernist, humanist narratives that appears earlier in the book. By positing incredulity toward metanarratives as the hallmark of a postmodern frame of mind, and by implying that this is the epistemological and ethical orientation he favours, Lyotard places himself in something of a bind. Attempts to cast him as a supporter of the neoliberal trends he identifies (cf. Mack, 2014) are misplaced, but Lyotard leaves himself exposed to such criticism given his refusal to speak definitely of these developments as unjust or undesirable. His ethical and political ideas were developed more fully elsewhere (Lyotard, 1988, 1993), and, taken collectively, those writings provide a clearer picture of what he might have to say in responding to neoliberalism. In The Postmodern Condition his ostensible concern is more specific: he is completing a commissioned report. Still, regardless of the status and purpose of The Postmodern Condition, Lyotard cannot, given his tacit espousal of a relativist moral position, make a strong case to show that the changes discussed in his narrative are ethically "wrong" or undesirable. We do not need to be so cautious. Despite the fact that the victory of the 
performativity principle is not complete, and the age of the Professor is not yet dead, there are deeply worrying signs.

These have to do, in large part, with the growing influence (predicted by Lyotard) of multinational corporations over everyday lives. In particular, it is the enormous power exercised by tech giants such as Google that must be problematized, questioned and contested. Google plays a key role in "regulating" and "controlling" the circulation of information along the lines envisaged by Lyotard. Universities, along with other educational institutions, have felt the effects of "Googlization" (cf. Peters, 2012; Vaidhyanathan, 2009). Control is established via the vast quantities of data collected through its search engine, and by the way those employing the engine are directed to some sites as their first choices over others. Preferences are shaped by the advertising dollars Google collects from other corporates, such that the "language games" played by those surfing the Internet are far from neutral. They are not, in Lyotard's terms, games of perfect information. Tastes, preferences, attitudes, decisions, and actions can all be heavily influenced by where browsers' eyes are directed as they undertake searches on the Internet. Of course, other search engines can be employed, but Google's technical sophistication, its aggressive promotion of its own products, and its global dominance make it difficult for competitors to win over potential browsers. It is not just the sheer volume of data that is significant here; it is also what Google does with the data. Default privacy settings provide a remarkably low level of protection for browsers. Searches are stored and, over time, with the application of complex algorithms, patterns of browsing activity create a picture of an individual's wants, interests and possible purchases. Those browsing the Internet may think they are invisible, but many of their physical characteristics (e.g., their approximate age and their gender) will quickly become evident. Information is being traded and exchanged under such a system, but not on an equitable basis.

The changes that were already underway in Lyotard's time in separating "knowledge" from "knowers" have continued, on multiple fronts, and this has contributed to a progressive dying away of being in favour of having. Performance-based systems of research assessment have not only contributed to ongoing productivity among academics in their publishing activities but have also played a role in advancing the commodification of knowledge and replacing it with the idea of performance (Roberts, 2006, 2013). To perform under such schemes, it is not necessary to demonstrate what one knows, or why, or even that one knows at all. Nor is there any requirement to show that one has taught others how or why to know. The emergence of performance-based research funding is consistent with the wider encroachment of cultures of measurement in university life. Teaching is frequently reduced to the same logic, 
with "teaching effectiveness" supposedly being determined by student ratings on 5-point scales. Such tendencies are evident on a much larger scale, with international league tables that rank universities against each other (e.g., the QS and Times Higher rankings) and global testing regimes such as PISA that compare one country against another in school performance across different subject areas. League tables of this kind have been heavily criticised, but they seem to be here to stay. They generate considerable anxiety at all levels in the education system and more widely, from individual students and teachers, to institutional leaders and politicians. Over the last two to three decades, measurement has increasingly been viewed as very much a positive influence in education: a way of generating greater certainty in assessing progress and in determining priorities for the investment of limited resources (cf. Roberts, 1997; Webster, 2017). In the contemporary world, the obsession with measurement is by no means limited to education. With the widespread use of social media, for example, value and status are frequently construed in terms of the number of hits a website receives or the number of subscribers a You Tube account has obtained.

The emergence of discourses on "evidence" in education (e.g., claims that teaching should be "evidence-based") is a further exemplification of these trends. It converges with the growing application of "big data" analytics and algorithmic thinking within education and more broadly (see further, Argenton, 2017; Attaran, Stark \& Stotler, 2018; Ben-Porath \& Shahar, 2017; Cope \& Kalantzis, 2015; Daniel, 2015; Eichhorn \& Matkin, 2016; Peters, 2012; Petrilli, 2018; Prinsloo, 2017; Schouten, 2017; Thompson, 2017; Wang, 2017; Williamson, 2017, 2018). With the aid of powerful computers and search engines, vast quantities of data can now be sifted, sorted, packaged, and produced. Huge data sets can be employed to inform policy decisions, structure educational interventions, and prioritise the spending of public funds. Lyotard foresaw that access to and control over information would be a critical factor in battles for global power in the future, and in the world of big data this struggle for domination can be played out in a particularly dramatic way. The very label "big data" itself speaks volumes about what is at stake here; it suggests something large and imposing, a force to be reckoned with. Data can dominate, rendering the dissenting individual Professor powerless. The numbers provided through appeals to big data are supposed to speak for themselves. Data may have to be interpreted by human beings, but even that process is increasingly being systematised and streamlined. The aim seems to be to reduce the complexity, the messiness, the unpredictability of education - to remove, as much as possible, the "human" element from the process. With data at their fingertips, politicians, officials and institutional leaders can feel emboldened - armed, as it were - in making 
decisions that would otherwise be hard to sell. In the era of big data, questions of ethics are assumed to no longer be relevant or central to the educational process. The dominance of scientific knowledge is being reasserted, bolstered by the "market knowledge" that sustains neoliberal forms of life (cf. Roberts, 2004).

At one point in The Postmodern Condition Lyotard creates the memorable image of the system as "a vanguard machine dragging humanity after it, dehumanizing it in order to rehumanize it at a different level of normative capacity" (p. 63). Technocrats claim that members of a society cannot know what they need; they are compromised by the fact that they are not "variables independent of the new technologies" (p. 63). This, Lyotard suggests, betrays both arrogance and blindness. The reference to de/humanisation here is of particular interest given the focus of this paper. Lyotard does not elaborate on what humanisation might mean, but the links between his observation and the contemporary world of performance measurement and big data analytics are worthy of further reflection. What we have now, it could be argued, is not so much a "takeover" by the machines, but something equally problematic from an ethical - and educational - point of view: the creation of increasingly $m a-$ chine-like processes for the production, conveying and evaluation of academic content. In performance-based research funding schemes, the language of "outputs" dominates. Strong incentives are in place to produce more outputs, in better journals, with greater "impact". At present, in Britain's Research Excellence Framework and in New Zealand's Performance-Based Research Fund, there is still the important element of peer review, with panels assigned to judge the submitted portfolios of fellow researchers across different disciplinary areas. But this is comparatively expensive and inefficient; it breaks the rules of the performativity principle, and pressure to reduce such costs in time and money and to ease the decision-making process will continue to grow. Removing the human element and replacing this entirely with a numbers-driven system (based, for example, on the number of publications, the ranking of journals, citation counts, the dollars gained in external research income, the number of research students supervised to completion, the hits on a social media account, and so on) would be consistent with changes already underway elsewhere.

The dehumanising character of these changes speaks directly to the theme of death. Dehumanisation can be seen as a life-denying process. It denudes human beings of their dignity and diminishes the place of the unique individual Professor (or student) in academic affairs. In the relentless drive for efficiency, with big data employed to further this end, there is a denial of the 
distinctiveness of each educational situation. Dehumanisation is destructive: it involves a kind of violence toward, or violation of, something that is worth preserving. The application of the performativity principle is, however, not a sign of strength but of weakness. It represents, among other things, a refusal to pay attention - to the particulars, the interactions, the unexpected developments that give educative moments value and character. Seen in this light, dehumanisation can be a very subtle process. The "terror" of our current era lies not so much in any sudden, traumatic event but more in the gradual, almost invisible "wearing down" of academics via managerialist structures and practices. It lies in the small concessions made every day to the logic of performativity. "Dying" becomes a normal mode of academic being. It is important not to romanticise the past; pressures to "perform" have always existed. We also need to acknowledge how hard it is to analyse changes while being carried along with them. Nevertheless, in reflecting on the time that has passed since Lyotard wrote The Postmodern Condition, it is clear that much of significance has been lost - slowly, steadily, sometimes invisibly. The academy of old cannot ever be fully recovered, but all new eras retain traces of the old and there is no "pure" transition from one moment in history to the next.

\section{4}

\section{Conclusion}

If, as has been argued above, what we are witnessing is the dying rather than the death of the age of the Professor, the increasing use of numbers, data and systems of performance measurement might be seen as the loudest bell that is currently ringing to signal this dying. The situation remains poised on a knife edge. On the one hand, there is a relentless drive to conform to the dictates of the performativity principle; to reduce knowledge to information, and to remove distracting "human" elements from the educational process. The power wielded by multinational corporations in managing and manipulating data can, in conjunction with the decisions made by national and international governing bodies, make individual Professors and their students seem irrelevant; they become fodder in the giant machine to which Lyotard refers, being dragged along by it regardless of their individual views of what education can or should be. On the other hand, the new technologies have created fresh opportunities for creative, critical individual and collective work in higher education. A process of dying holds open the possibility of revival or rebirth, if circumstances are favourable for this, and it is possible that a new age of the Professor - in a computerised but not necessarily dehumanised world - will 
emerge in the years ahead. We cannot know exactly what that age will look like but we can work toward retaining the best from the humanistic university of the past while keeping an open mind about the academy of the future.

\section{References}

Argenton, G. (2017). Mind the gaps: Controversies about algorithms, learning and trendy knowledge. E-Learning and Digital Media, 14(3), 183-197.

Attaran, M., Stark, J. \& Stotler, D. (2018). Opportunities and challenges for big data analytics in US higher education: A conceptual model for implementation. Industry and Higher Education, 32(3), 169-182.

Baggaley, J. (2013). моoc rampant. Distance Education, 34(3), 368-378.

Ben-Porath, S. \& Shahar, T.H.B. (2017). Big data and education: Ethical and moral challenges. Theory and Research in Education, 15(3), 243-248.

Billsberry, J. (2013). Moocs: Fad or revolution? Journal of Management Education, 37(6), 739-746.

Cope, B. \& Kalantzis, M. (2015). Sources of evidence-of-learning: Learning and assessment in the era of big data. Open Review of Educational Research, 2(1), 194-217.

Daniel, B. (2015). Big data and analytics in higher education: Opportunities and challenges. British Journal of Educational Technology, 46(5), 904-920.

Eichhorn, S. \& Matkin, G.W. (2016). Massive open online courses, big data, and education research. New Directions for Institutional Research, 167, 27-40.

Evans, S. \& McIntyre, K. (2016). Moocs in the humanities: Can they reach underprivileged students? Convergence: The International Journal of Research into New Media Technologies, 22(3), 313-323.

Fitzsimons, P., Peters, M. \& Roberts, P. (1999). Economics and the educational policy process in New Zealand. New Zealand Journal of Educational Studies, 34(1), 35-44.

Gietzen, G. (2010). Jean-Francois Lyotard and the question of disciplinary legitimacy. Policy Futures in Education, 8(2), 166-176.

Guardia, L., Maina, M. \& Sangra, A. (2013). Mooc design principles: A pedagogical approach from the learner's perspective. eLearning Papers, 33, 1-5.

Howarth, J.P., D'Alessandro, S., Johnson, L., \& White, L. (2016). Learner motivation for MOOC registration and the role of MOOCs as a university "taster". International Journal of Lifelong Education, 35(1), 74-85.

Irwin, J. (2018). Radicalising philosophy of education - The case of Jean-Francois Lyotard. Educational Philosophy and Theory, 5o(6-7), 692-701.

Jona, K. \& Naidu, S. (2014). Moocs: Emerging research. Distance Education, 35(2), $141-144$. 
Koller, H-C. (2003). Bildung and radical plurality: Towards a redefinition of Bildung with reference to J-F. Lyotard. Educational Philosophy and Theory, 35(2), 155-165.

Lange, J. (2015). Rise of the digitized public intellectual: Death of the professor in the network neutral Internet age. Interchange: A Quarterly Review of Education, 46, 95-112.

Locke, K. (2015). Performativity, performance and education. Educational Philosophy and Theory, 49(3), 247-259.

Longstaff, E. (2017). How Moocs can empower learners: A comparison of provider goals and user experiences. Journal of Further and Higher Education, 41(3), 314-327.

Lyotard, J-F. (1984). The postmodern condition: A report on knowledge (G. Bennington \& B. Massumi, Trans.). Minneapolis, MN: University of Minnesota Press. (Original work published 1979).

Lyotard, J-F. (1988). The differend: Phrases in dispute (G.V.D. Abbeele, Trans.). Minneapolis, MN: University of Minnesota Press.

Lyotard, J-F. (1993). Political writings (B. Readings \& K.P. Geiman, Trans.). Minneapolis, MN: University of Minnesota Press.

Mack, M. (2014). Philosophy and literature in times of crisis: Challenging our infatuation with numbers. New York, NY: Bloomsbury.

Marshall, J. (1999). Performativity: Lyotard and Foucault through Searle and Austin. Studies in Philosophy and Education, 18, 309-317.

Ministry of Education (2006). Tertiary education strategy, 2007-12. Wellington: Ministry of Education (Office of the Associate Minister of Education - Tertiary Education).

Ministry of Education (2009). Tertiary education strategy, 2010-15. Wellington: Ministry of Education (Office of the Minister for Tertiary Education).

New Zealand Government (2014). Tertiary education strategy, 2014-2019. Wellington: Ministry of Education and Ministry of Business, Innovation and Employment.

New Zealand Productivity Commission (2017). New models of tertiary education: Final Report. www.productivity.govt.nz/inquiry-content/tertiary-education.

Nussbaum, M. (2010). Not for profit: Why democracy needs the humanities. Princeton: Princeton University Press.

Nuyen, A.T. (1992). Lyotard on the death of the professor. Educational Theory, 42(1), 25-37.

Peters, M. (1989). Techo-science, rationality, and the university: Lyotard on the "postmodern condition". Educational Theory, 39(2), 93-105.

Peters, M. (Ed.) (1995). Education and the postmodern condition. Westport, CT: Bergin and Garvey.

Peters, M. (1997). Wittgenstein and post-analytic philosophy of education: Rorty or Lyotard? Educational Philosophy and Theory, 29(2), 1-32.

Peters, M.A. (2006). Lyotard, nihilism and education. Studies in Philosophy and Education, 25, 303-314. 
Peters, M.A. (2012). Algorithmic capitalism and educational futures: Informationalism and the Googlization of knowledge. Truthout, 4 May.

Peters, M. \& Roberts, P. (1999). Globalisation and the crisis in the concept of the modern university. Australian Universities' Review, 42, 47-55.

Petrilli, M.J. (2018). Big data transforms education research. Education Next, Winter, $86-87$.

Prinsloo, P. (2017). Fleeing from Frankenstein's monster and meeting Kafka on the way: Algorithmic decision-making in higher education. E-Learning and Digital Media, 14(3), 138-163.

Roberts, P. (1997). A critique of the NZQA policy reforms. In M. Olssen \& K. Morris Matthews (Eds.) Education policy in New Zealand: The 1990 and beyond (pp. 162-189). Palmerston North: Dunmore Press.

Roberts, P. (1998). Rereading Lyotard: Knowledge, commodification and higher education. Electronic Journal of Sociology, 3(3).

Roberts, P. (2004). Neoliberalism, knowledge and inclusiveness. Policy Futures in Education, 2(2), 350-364.

Roberts, P. (2006). Performativity, measurement and research: A critique of performance-based research funding in New Zealand. In J. Ozga, T. Popkewitz, \& T. Seddon (Eds.) World Yearbook of Education 20o6: Education Research and Policy (pp. 185-199). London: Routledge.

Roberts, P. (2007). Intellectuals, tertiary education and questions of difference. Educational Philosophy and Theory, 39(5), 480-493.

Roberts, P. (2013). Academic dystopia: Knowledge, performativity and tertiary education. The Review of Education, Pedagogy, and Cultural Studies, 35(1), 27-43.

Schouten, G. (2017). On meeting students where they are: Teacher judgement and the use of data in higher education. Theory and Research in Education, 15(3), 321-338.

Thompson, G. (2017). Computer adaptive testing, big data and algorithmic approaches to education. British Journal of Sociology of Education, 38(6), 827-840.

Usher, R. (2006). Lyotard's performance. Studies in Philosophy and Education, 25, 279-288.

Vaidhyanathan, S. (2009). The Googlization of universities. The 2009 NEA Almanac of Higher Education, 65-74.

Wang, Y. (2017). Education policy research in the big data era: Methodological frontiers, misconceptions, and challenges. Education Policy Analysis Archives, 25 (94), 1-21.

Webster, R.S. (2017). Valuing and desiring purposes of education to transcend miseducative measurement practices. Educational Philosophy and Theory, 49(4), 331-346.

Williamson, B. (2017). Who owns educational theory? Big data, algorithms and the expert power of education data science. E-Learning and Digital Media, 14(3), 105-122. 
Williamson, B. (2018). The hidden architecture of higher education: Building a big data infrastructure for the "smarter university". International Journal of Educational Technology in Higher Education, 15(12), 1-26.

Zembylas, M. (2000). Something 'paralogical' under the sun: Lyotard's Postmodern Condition and science education. Educational Philosophy and Theory, 32(2), 159-184. 